Dugdale, D. and Abdel-Kader, M. (1999), Funding Issues in a Major Strategic Project: A Case of Investment Appraisal, Accounting Education: An International Journal, Vol. 8, No. 1, pp. 31-45. ISSN 0963-9284. doi: 10.1080/096392899331026. Definitive version available online at: http://www.informaworld.com/smpp/title content=t713683833

\title{
Funding Issues in a Major Strategic Project: A Case of Investment Appraisal
}

\author{
David Dugdale \\ Bristol Business School, University of the West of England, Bristol, Frenchay Campus, \\ Bristol BS16 1QY \\ Magdy G. Abdel-Kader \\ School of Business and Economics, University of Exeter, Exeter EX4 4PU
}

(Corresponding author)

Email: Magdy.Kader@brunel.ac.uk

Acknowledgement: The authors acknowledge the co-operation and encouragement of the Finance Director of UKH Company, in the preparation of this case. Any errors that may remain in the manuscript are, of course, the responsibility of the authors.

\begin{abstract}
This paper describes and allows interaction with the issues involved in a major investment decision. In the summer of $1997, \mathrm{UKH}^{1}$ faced major decisions concerning the purchase and funding of new plant and equipment. The authors were given excellent access to the company and were able to document key steps in the decision process.

The issues are set out in a case study format that allows the reader to retrace the analyses carried out within UKH. A number of tasks are suggested that should test, develop and enhance a range of analytical, social and negotiation skills.

The case can be handled in a variety of ways and most of the suggested tasks can be undertaken or omitted depending on the pedagogical objectives of the course/ instructor.

Keywords: Investment decision, finance, case study.

\section{Introduction}

This paper describes the issues involved in a major investment decision faced by UKH, a major operator in the UK transport industry, in the summer of 1997. As a condition of operating leases won by the company, equipment had to be replaced and the company had to decide whether this should be leased or purchased and how to raise the necessary finance. The authors were allowed full access to key documents and were able to record the decision process as it unfolded over a period of months. The data presented is realistic and faithfully reflects the economic realities faced by UKH management. However, the final financial
\end{abstract}

\footnotetext{
${ }^{1}$ Throughout this paper the case study is referred to as UKH (UK Holdings) in order to maintain confidentiality.
} 
arrangements ultimately made between UKH and its banker are not revealed in order to maintain commercial confidentiality.

A case study style presentation has been chosen so that the reader can gain insights into the issues that arose in making a major investment decision and in raising finance to fund it. Particular features of the case include the interaction between investment decision making and financing and the opportunity to simulate commercial reality by a role playing exercise in which participants take the parts of UKH and a merchant bank.

The case is set out in a manner which should make it easy to use as a teaching aid. Separate sections cover background information, project cashflows, financial analysis, financing the project and financial structure and student tasks are set at the end of each section. These tasks allow students to work through the case, retracing the analysis carried out within UKH. A number of technical issues arise: valuation of an annuity; capital allowances and tax effects; calculating internal rates of return and net present value; and identifying an appropriate cost of capital. Students need a good knowledge of basic financial management, an understanding of sensitivity analysis and spreadsheet skills in order to deal with these issues. A comprehensive reference for the investment appraisal and finance aspects of the case would be Brealey and Myers (1996). However, most of the knowledge needed could equally be found in a standard management accounting textbook such as Drury (1996), chapters 15 and 16, (pp 383-460). There are many texts and manuals dealing with IT in general and spreadsheets in particular, but Mayes and Shank (1996) stands out because of its focus on the application of spreadsheet methods to problems in financial analysis.

The last part of the case focuses on the negotiation between UKH and a merchant bank and here students need both technical skills (in order to foresee the consequences of particular outcomes) and inter-personal and negotiation skills in order to reach a settlement which is acceptable to both parties. See figure 1 for an overview of possible student activities.

If used in its entirety, the case requires a significant time commitment. An instructor could spend thirty minutes introducing the case and giving initial guidance; attempting the technical aspects of the case will take typical students between three and six hours; and the negotiation and subsequent analysis of outcomes could require two hours of class time. The case has been tested at Masters level (MA, Finance) and students were positive about the insights gained into the practical application of theoretical methods and the commercial issues which arise in a really significant investment decision.

While the case can be quite time consuming, it is possible to abbreviate it without losing its coherence. For example, the first task (a technical aside) could be omitted and, in task 4, students can simply be given (instead of being asked to calculate) the costs of raising debt finance and servicing the initial loan. By adopting appropriate variations the case can be used at both postgraduate and advanced undergraduate levels and it should be especially useful in finance and financial management options at masters level.

\section{Background}

UKH comprises two wholly owned subsidiaries and these subsidiaries hold operating franchises in separate regions of England and Wales. The franchises were won in 1995 when the then Conservative government extended its privatisation programme. In the first instance, operating franchises were awarded for a limited period and it was understood that holders would have to bid again when the franchises expired. One of the conditions of the franchises was that a significant investment in plant and equipment would be undertaken during the course of the franchise period. This case deals with the investment and funding issues which arose from this requirement. 
The board of directors of UKH saw its financing options as twofold. Either the new equipment could be leased or it could be purchased. The first alternative would minimise risk because if the Group were to lose its operating franchise, it would not face the problem of disposing of illiquid assets. The alternative was to purchase. This would ensure that UKH remained in the transport business because, even if operating franchises were lost, the Group would remain a major player in the business through its ownership of key assets, which could be rented or leased to other operators.

The inclination of the Board was to adopt the second option, to purchase and there were a number of strategic reasons which are outside the scope of the case for this preference.

However, while disposed toward purchasing rather than leasing new plant and equipment the Board needed to be assured that its preferred strategy was financially attractive. In order to address this issue the Finance Director of UKH proposed that, if new plant and equipment were purchased, it should be owned by a new company within UKH - Leaseco Ltd. Leaseco would purchase the required equipment and lease it to the operating company (one of the existing subsidiaries of UKH). The Financial Director set out his reasons for this proposal:

1. The establishment of Leaseco would clearly separate financial from operating issues.

2. The new company could be established in a manner which would isolate it from UKH if the new operation were to become insolvent.

3. The new company would facilitate joint venture arrangements which could be important in funding the new enterprise.

\section{Project Cashflows}

In order to evaluate the proposal the Finance Director needed to estimate the stream of income which would accrue to Leaseco as a result of leasing equipment to operators (the UKH subsidiary in the first instance but, possibly, other operators after the first franchises expired.) This cash stream was based on "arms length" estimates of the cost of operating leases. Income was assumed to commence in the year 2000 and to continue for 26 years when the equipment was assumed to have a residual value of about $£ 25$ million. (In review it was suggested that the value of $£ 25$ million after 26 years operation seemed unduly optimistic. However, the residual value of $£ 25$ million will be discounted over 26 years and the analysis will not therefore be particularly sensitive to this assumption.) The cash flows are set out in Appendix 1. The assumptions on which the cash flows were based are outside the scope of the case but they included:

1. An inflation assumption - assuming that transportation prices would inflate at between 2 and $3 \%$ per annum.

2. A utilisation assumption - assuming that between 60 and $100 \%$ of the plant and equipment could be re-leased throughout the 26 year life of the project.

3. An "obsolescence" assumption - assuming that as the plant and equipment became older it would command a less attractive price in the market place.

The cash flow forecasts were thought to be of good 'quality': the assumptions made were conservative and a significant element of the projected income was underpinned by Government subsidies and commitment. An assumption was also made concerning the value of the cash flows received. In order to facilitate analysis it is conventionally assumed that all project cash flows take place at year ends. In this project, the lease income would be received monthly and so the conventional end-year assumption would penalise the project (especially given its long life). In order to overcome this technical problem the Finance Director uprated the projected annual cash flows by a factor of $4.5 \%$. (The cash flows set out in Appendix 1 
have already been uprated by this factor). The factor was based on the assumption that income received could earn a before-tax rate of return of $10 \%^{2}$.

Task 1: Validate the factor of $4.5 \%$ used to uprate the value of incoming cash flows.

Having established an estimate of the gross cash flows the Finance Director now had to assess whether the project was viable. A number of potential suppliers were asked to quote and, taking account of the technical specification, service arrangements and price, a preferred supplier was selected. The quoted price from this supplier was $£ 64.5$ million for plant and equipment to be available on January 1, 2000. The rate of corporation tax appropriate to the project was $31 \%$ and capital allowances calculated on a $25 \%$ reducing balance basis for tax purposes were available ${ }^{3}$. Tax was assumed payable approximately one year in arrears.

Task 2: Establish the after tax cash flows. Calculate the payback and the internal rate of return of the project. What further information is needed in order to establish whether the project is viable?

\section{Financial Analysis}

In order to assess the viability of the project an estimate of the cost of capital of the project was needed. The Finance Director approached a number of merchant banks in order to establish how much funding could be raised by debt finance and found that it would not be difficult to borrow $90 \%$ of the cost - some $£ 58$ million. The interest charge on this loan was expected to be between $1.5 \%$ and $4 \%$ above bank base rate $(7.37 \%$ when the project was under consideration). The remaining $£ 6.5$ million of funding required would have to be injected as equity finance, and UKH had set a target of $20 \%$ return (before tax) for such finance.

\section{Task 3: Calculate the cost of capital for the project and assess its viability.}

\section{Financing the Project}

Having determined the parameters within which the project was viable the Finance Director then approached the merchant banks with a clear specification of his requirements. The plant and equipment would be manufactured in the period 1998 - 2000 and a loan of $£ 58$ million would be drawn down over this period in order to make staged payments to the contractor. The schedule of staged payments is set out in Appendix 2.

\footnotetext{
${ }^{2}$ A reviewer suggested that the assumption of a $10 \%$ before-tax return might be optimistic. However, the assumed return of $10 \%$ before-tax must be related to economic circumstances in the UK at the time of writing. The before-tax cost of borrowing was $8 \%$ to $9 \%$ and, in this context, the assumption that the company could earn $10 \%$ before-tax seems sensible to the authors. Most importantly a $10 \%$ return was actually assumed by UKH.

${ }^{3}$ The system of tax allowances in the UK, at the time of writing, was based on the reducing balance method of depreciation. Thus, an investment of $£ 10$ million would attract a capital allowance of $£ 2.5$ million in its first year. In its second year it would attract an allowance of $£ 1.875$ million ( $£ 7.5$ million $\times 25 \%$ ). If an asset is sold a 'balancing allowance' is calculated (which might be positive or negative) based on the difference between the sale price of the asset and its written down value for tax purposes (for more details, see, for example, Davis and Pointon, 1994, Ch. 9).
} 
The contractor required that the funds necessary to finance manufacture be available when the contract was signed and the banks were therefore asked to quote their terms for a loan of $£ 58$ million to be available from October 1997. Appendix 3 sets out the key paragraphs from a typical quotation. It was not untypical for a bank to require arrangement fees, commitment fees and underwriting arrangements as well as (of course) interest on any portion of the loan drawn down during the period 1997 - 2000. Whilst the fees appeared relatively expensive this was, to some extent, offset by the willingness of banks to negotiate competitive interest rates.

Task 4: Establish the total project costs during the period 1997 - 2000. Does this affect your judgement of the project's viability? Reconsider the project cost of capital in the light of your analysis. Does this affect your judgement of the project's viability?

\section{The Financial Structure}

It was eventually concluded that the project was intrinsically viable and whether the project was to go ahead then depended upon reaching an agreement with one of the banks. The issues which arose at this stage of the project are best understood by a simulated role play exercise with participants representing the bank and UKH. Negotiations start from the last quotation by the bank (as set out in Appendix 3).

As an aside, one of the banks expressed its interest in joining UKH as a shareholder in Leaseco with the following proposed capital structure for the jointly owned company:

$\begin{array}{llr} & & £ \mathrm{~m} \\ \text { Debt capital: } & & 58.0 \\ \text { Equity capital: } & \text { Bank: } & 2.0 \\ & \text { UKH: } & 4.5 \\ & & 64.5\end{array}$

The bank would expect $30.7 \%$ of the after tax earnings of Leaseco as dividends (based on its $30.7 \%$ share of the equity of the company). $69.3 \%$ of the after tax earnings would accrue to UKH. [This proposal eventually came to nothing but the reader may wish to consider whether the proposal as formulated is attractive to Leaseco.]

Task 5: Negotiation between UKH and the bank. See figure 2. 


\section{The Case of UKH: Teaching Notes}

The first part of the case sets out the assumptions and expected cash flows associated with the proposed purchase. Two tasks are set at this stage. The first task is a technical exercise to check that an uprate factor of $4.5 \%$ correctly takes into account monthly (rather than endyear) cash flows. This was important in the case because of the long time span involved (26 years) and the consistently pessimistic bias which would be introduced if the effect were ignored. The first task can, however, be omitted without affecting the remainder of the case material. The second task requires that the project be evaluated over its twenty-six year life, taking into account capital allowances and tax implications. A spreadsheet needs to be constructed to carry out this analysis efficiently.

The third task switches to the funding of the project and requires calculation of an appropriate weighted average cost of capital. This task is quite straightforward given the information available- that $90 \%$ of the funding can be raised as debt while the remaining $10 \%$ will be UKH equity. The reader is invited to assess the viability of the project, and, even if a pessimistic assumption is made about the cost of borrowing, the project seems attractive.

The next part of the case requires careful study of a few key paragraphs from a typical bank contract. These paragraphs are presented in Appendix 3 and represent the distillation (and considerable simplification) of the proposals received.

Despite the simplified nature of the information, the fourth task is not simple. It requires that the costs of raising debt finance and servicing the loan be estimated. Degrees of refinement are possible and the time value of money may be taken into account. The total cost is about $£ 5$ million. However, the key issue here is not precise calculation, it is careful analysis of the proposed contract to ensure that it is well understood and all its implications are taken into account. Students attempting this task will need guidance and the instructor might point out that the actual contracts received were several pages in length. It is difficult to overestimate the importance of reading such contracts carefully. Important clauses were contained in the small print! If desired, task 4 can be omitted. Students can simply be advised that loan charges amount to $£ 5$ million and asked to re-assess the project.

Whilst tasks 1-4 are primarily technical exercises, task 5 attempts to simulate, by means of a role play, the negotiation between UKH and its potential banker. Vital to this negotiation is an understanding of the cash flows that will accrue to the bank and to UKH. A typical spreadsheet analysis is provided (figure 5) to which students might be guided. The schedule of repayments proposed by the bank leads to an unsatisfactory result for UKH and the key issue is whether terms can be negotiated which satisfy both parties. Students should find this enlightening and they should begin to realise the importance of comprehensive preparatory financial calculations if a good outcome is to be achieved.

Students are likely to find task 5 more interesting if a competitive aspect is introduced into the role play exercise. Suppose that the class can be conveniently divided into five groups, two representing UKH and three representing banks. The 'banks' could be briefed to the effect that this would be a good contract to win because it might lead to more business as other operators sought finance under the terms of their operating franchises. They could be asked to table revised offers - to be made available to the two UKH teams. The UKH teams could then negotiate with any (or all) of the bank teams with the aim of reaching the best deal possible. At the end of the exercise one bank might have won the contract with both UKH teams or two separate banks might have won contracts. The reason why one or two banks got the contract and one (or two) did not would be very enlightening and these could be revealed in plenary session. Whether 'UKH' or a particular 'bank' had achieved a good (or a poor) 
deal would be assessed by the instructor and, if the case were assessed, credit could be given for closing the deal and for the value of the contract won.

Task 1

Task 1 is a technical exercise in order to check that the factor of $4.5 \%$ used by the Finance Director to uprate annual cash flows (because these are received monthly) is valid. The FD assumed an annual $10 \%$ before tax return in this calculation.

First the annual return has to be converted to a monthly figure:

$$
\sqrt[12]{1.1}=1.007974
$$

And the equivalent monthly interest rate is $0.7974 \%$

Applying this rate of interest to a 12 period annuity (of $£ 1$ per period):

$$
\text { Value }=\frac{1.007974^{12}-1}{1.007974-1}=12.5408
$$

So twelve monthly payments of $£ 1$ are worth $£ 12.54$ (not $£ 12$ ). An annual sum received monthly is actually worth:

$$
\frac{12.54}{12.00}=1.045
$$

That is $4.5 \%$ more than it appears.

\section{Task 2}

Task 2 involves a relatively simple calculation - so long as the reader is conversant with the uses of spreadsheets! A typical spreadsheet analysis is set out in figure 3.

Column 2 reflects the expected cash flows (per Appendix 1 in the case). Column 3 shows the tax liability associated with these cash flows lagged by one year to allow for the normal delay in settling tax liabilities. Column 4 is calculated as Column 2 less Column 3. Column 5 shows the written down balance of the investment taking a write down of $25 \%$ in each year and Column 6 shows the allowance itself. Column 7 calculates the tax credit associated with the allowance. Column 8 is the final after tax cash flow associated with the project.

Having established the after tax cash flows it is a simple matter to calculate the project internal rate of return. The Excel function has been used to calculate this as 9.49\%. Column 8 in the spreadsheet shows the calculations needed to calculate the project's payback period which is slightly more than 9 years.

Whether the project is viable cannot be ascertained without some estimate of the cost of capital associated with the project - the subject of the next task.

\section{Task 3}

If borrowing from the bank can be arranged at a very favourable rate $(1.5 \%$ above base rate is assumed here) then the weighted average cost of capital for the project can be calculated as follows. Remember that the 'tax shield' should be taken into account for debt finance so the after-tax cost of debt is $8.87 \times(1-0.31)=6.12 \%$

$$
\begin{array}{ll}
90 \% \text { debt finance at } 6.12 \%: & 5.5083 \\
\text { 10\% equity finance at } 13.8 \% \text { : } & \underline{1.3800} \\
\text { Weighted average cost of capital } & \underline{6.8883}
\end{array}
$$

On this basis the project appears viable since the cost of capital, at just $6.9 \%$ is significantly below the project internal rate of return. The net present value of the project at a discount rate of $6.9 \%$ is about $£ 14$ million.

If a pessimistic view of the cost of debt finance were adopted (base rate plus 4\%) then the weighted average cost of capital would be calculated as $8.44 \%$. Obviously this is significantly higher than the optimistic assumption, but, on the assumptions to date, the project would still be viable with a net present value of $£ 5$ million when discounted at $8.44 \%$. 
Students should be encouraged to undertake further sensitivity analysis on variables such as: projected cash flows, residual value, the $10 \%$ return assumption in task 1 , and tax rates. In judging the viability of the project, however, it should be borne in mind that the directors of UKH considered projected base cash flows to be conservative (being derived from conservative assumptions for price inflation and utilisation.)

Task 4

Taking account of all the fees and interest payable on the loan during the period October 1997- December 1999 is quite complex. The spreadsheet used in the analysis is presented in figure 4.

In this spreadsheet the various payments to the contractor, to the bank and to the residual value guarantor are listed in columns 2, 3 and 4 . It is assumed that these are met by drawing down the loan from the bank and this leads to an interest charge on the outstanding loan (column 5). The interest is calculated at the bank's proposed rate of base rate plus $2 \%$ and the tax shield is taken into account in arriving at the effective after tax rate of $6.47 \%$. The outstanding loan is recorded in column 6 and it can be seen that the total invested would be $£ 53.6$ million at December 31, 1999. To this must be added the commitments in the period 2000 - 2002 and these commitments have been discounted at an after tax discount rate of 7\% per annum. (This discount rate is based on the estimated weighted average cost of capital for the project.)

Taking all the various charges and debt servicing into account the spreadsheet shows that the investment is about $£ 69.5$ million, some $£ 5$ million more than that used in the calculations for tasks 2 and 3.

This should, of course, lead to re-evaluation of the project. First, and most obviously, the revised value for the investment reduces the projected net present value of the project by $£ 5$ million. Second, not so obviously, the weighted average cost of capital for the project should be recalculated to take into account the need for substantially more equity capital. The calculation also recognises the bank's proposed interest rate of base rate plus $2 \%$ :

$$
\begin{array}{ll}
£ 11.5 \text { million equity at } 13.8 \%: & 1.587 \\
£ 58 \text { million debt at } 6.47 \% \text { : } & \underline{3.753}
\end{array}
$$

A weighted average cost of capital of 5.34/69.5 $=7.68 \%$

5.340

The inclusion of these revised figures in the spreadsheet (figure 3) shows the project generating an internal rate of return of $8.45 \%$ and a net present value of $£ 4.1$ million $^{4}$. The project is considerably less attractive than previously thought but, nevertheless, it still returns a healthy net present value - and this despite some fairly hefty charges which would surely be negotiable.

\section{Task 5}

Task 5 aims to simulate the "live" negotiation which took place between the Finance Director of Great Western Holdings and the banks (three banks were approached and their 'final' terms compared in order to reach a decision). In order to determine whether a particular deal was acceptable the Financial Director devised a spreadsheet which split the cash flows between those accruing to UKH and those accruing to the bank. This spreadsheet is presented in figure 5.

\footnotetext{
${ }^{4}$ The spreadsheet was amended by substituting $£ 69.5$ million in place of $£ 64.5$ million as the initial investment and $7.68 \%$ in place of $6.9 \%$ as the after tax cost of capital.
} 
The spreadsheet has been constructed by taking the project after tax cash flows (column 2) and dividing them between the bank and UKH's lease company, Leaseco. Column 6 shows the total return to the bank being the sum of the return of capital (column 4) and interest payments (column 5). Not surprisingly the return to the bank is $9.37 \%$, the rate of interest charged.

Columns 7 and 8 show the cash flows to Leaseco. Column 7 shows the tax relief associated with the interest payments and column 8 shows the project cash flows from Leaseco's point of view. Column 8 is calculated as the project cash flow (column 2) less the cash flows received and remitted to the bank (column 6) plus the interest tax credit (column 7). At first sight it may seem that the internal rate of return on Leaseco's cash flow at $10.7 \%$ is satisfactory. However, it must be remembered that this is a return on equity capital, and Leaseco's target return on equity is $20 \%$ before tax, $13.8 \%$ after tax.

This analysis shows that the division of project cash flows is not satisfactory to Leaseco. It might be expected that a negotiation between the bank and Leaseco would result in some concessions by the bank so that, eventually, both parties would be satisfied. Concessions might be made in respect of the interest rate charged, the loan charges and, most importantly, the repayment schedule. A deal was eventually struck which both parties were prepared to accept.

\section{References}

Brealey, R.A. and Myers, S.C. (1996) Principles of Corporate Finance. London: McGrawHill.

Davis, E., and Pointon, J. (1994) Finance and the Firm: An Introduction to Corporate Finance, 2nd ed. Oxford: Oxford University Press.

Drury, C. (1996) Management and Cost Accounting, 4th edition. London: International Thompson Business Press.

Mayes, T.R and Shank, T.M. (1996) Financial Analysis with Microsoft Excel, London: Dryden Press. 
Appendix 1

Projected Lease Income

Year

E’000

2000

6433

2001

6433

2002

6433

2003

6433

2004

7128

$2005 \quad 7314$

$2006 \quad 7504$

$2007 \quad 7555$

$2008 \quad 7752$

$2009 \quad 7953$

$2010 \quad 8160$

$2011 \quad 7928$

$2012 \quad 8134$

$2013 \quad 8346$

$2014 \quad 8159$

$2015 \quad 8194$

$2016 \quad 8406$

$2017 \quad 8625$

$2018 \quad 6721$

$2019 \quad 6896$

$2020 \quad 6730$

$2021 \quad 4670$

$2022 \quad 4791$

$2023 \quad 4916$

$2024 \quad 5044$

202525233 (being the estimated residual value of the equipment)

These are annual figures which have been uprated by a factor of $4.5 \%$ in order to take into account the monthly profile of lease income. 
Appendix 2

Schedule of Payments to the Manufacturer

Date

E'000s

Oct 97

2000

Mar 99

10872

Apr 99

5292

May 99

7812

Jun 99

5712

Jul 99

5376

Aug 99

4200

Sep 99

504

Oct 99

2197

Nov 99

2510

Dec 99

2510

Jan 00

4707

Feb 00

5021

Mar 00

5787

\section{Appendix 3}

Proposed Contract from the Bank

Maximum Facility

$£ 58,000,000$

\section{Facility Amortisation}

The facility shall be available from 1 October 1997 and the capital shall be repaid in quarterly instalments as follows:

Year

2000

2001

2002

2003

2004

2005

2006

2007

2008

2009

2010

2011

2012

2013

2014

2015

Interest

Annual Repayment
$\mathbf{E 0 0 0}$
5,000
5,000
5,000
5,000
4,000
4,000
4,000
4,000
4,000
4,000
4,000
2,000
2,000
2,000
2,000
2,000

LIBOR plus $2 \%$, compounded monthly on the outstanding balance of the loan.

Front End Fee

$£ 300,000$ payable 1 October 1997.

Commitment Fee

$0.5 \%$ payable quarterly in arrears on undrawn amounts. 


\section{Lender's Guarantees}

If the operating franchise is lost the borrower guarantees to repay the outstanding balance of the loan at December 31, 2003. In order to do this the borrower may refinance the loan but, should the borrower choose not to do this, there will be recourse to a Residual Value Guarantor who will guarantee to purchase the equipment for a sum of $£ 38,000,000$.

The Bank will nominate the Residual Value Guarantor who will require a fee of $3 \%$ of the residual value for this service. This fee $(£ 1,140,000)$ will be paid in annual sums of $£ 222,800$ commencing December 31, 1998 and concluding December 31, 2002.

\section{Figure 1. Overview of Student Activities}

Task 1 A technical exercise: to take account of monthly (rather than year-end) cash flows.

Task 2 Evaluate the project over its 26 year life.

Task 3 Funding issues: calculate an appropriate weighted average cost of capital.

Task 4 Commercial issues: study a typical bank funding proposal, calculate the cost of raising debt finance and re-assess the project.

Task 5 Negotiation: a role play exercise between representatives of UKH and the bank. 


\section{Figure 2. Negotiation Between UKH and the Bank Role for the Finance Director of UKH}

As Finance Director of UKH you should negotiate as a good a deal as you can for UKH. The major issues you need to consider are:

1. The fees you are willing to pay. The bank's initial quotation is almost certainly its initial bargaining position. You are aware that making large loans is inherently more profitable to the bank than making small loans. (So long as the borrower does not default).

2. The expected interest charges on outstanding debt. Obviously you want the minimum possible mark-up over bank base rate.

3. The debt repayment schedule. You probably want the repayment schedule to be extended over as many years as possible. (Because debt finance is, arguably, cheaper than equity finance).

\section{Role for the Bank's Negotiator}

As negotiator on behalf of the bank you should obtain as good a deal as you can for the bank.

You have three major objectives:

1. To cover all the bank's expenses in setting up and administering the loan and to make the bank's "normal” profit margin on this activity. (The bank's cost structure for large loans is normally reckoned to be about $£ 500,000$ "fixed" costs (for any loan) and about $0.5 \%$ of the loan in "variable" costs).

2. To obtain an acceptable return on the loan finance injected into the project by the bank. (Your minimum working assumption is bank base rate plus $1.5 \%$ for loan finance).

3. To minimise the bank's exposure should the project fail to deliver all the expected benefits. To this end you wish to negotiate an aggressive schedule of debt repayment during the first four years of the project - whilst income streams are secure because the initial franchises are operating.

\section{Outcomes}

The negotiation can be regarded as successfully concluded when the following issues have been agreed:

1. The interest rate on debt finance (stipulated as a premium over bank base rate).

2. The schedule of debt repayment to the bank.

3. The fees payable to the bank by Leaseco for arranging the loan, commitment and underwriting. 


\begin{tabular}{|c|c|c|c|c|c|c|c|c|}
\hline Figure 3 & Calculati & s of Payb & back Perio & d, Interna & Rate of $F$ & eturn anc & Net Pres & sent Value \\
\hline Col. 1 & Col. 2 & Col. 3 & Col. 4 & Col. 5 & Col. 6 & Col. 7 & Col. 8 & Col. 9 \\
\hline Year & Cash flow & Tax & Cash flow & Written & Allowances & Tax credit & After tax & Payback \\
\hline & & payable & after tax & down value & & & cash flow & calculation \\
\hline & $£^{\prime} 000$ & $£^{\prime} 000$ & $£^{\prime} 000$ & $£^{\prime} 000$ & $£^{\prime} 000$ & $£^{\prime} 000$ & $£^{\prime} 000$ & \\
\hline 1999 & -64500 & & & 64500 & & & -64500 & -64500 \\
\hline 2000 & 6433 & & 6433 & 48375 & 16125 & 4999 & 11432 & -53068 \\
\hline 2001 & 6433 & 1994 & 4439 & 36281 & 12094 & 3749 & 8188 & -44880 \\
\hline 2002 & 6433 & 1994 & 4439 & 27211 & 9070 & 2812 & 7251 & -37630 \\
\hline 2003 & 6433 & 1994 & 4439 & 20408 & 6803 & 2109 & 6548 & -31082 \\
\hline 2004 & 7128 & 1994 & 5134 & 15306 & 5102 & 1582 & 6715 & -24367 \\
\hline 2005 & 7314 & 2210 & 5104 & 11480 & 3827 & 1186 & 6291 & -18076 \\
\hline 2006 & 7504 & 2267 & 5237 & 8610 & 2870 & 890 & 6126 & -11950 \\
\hline 2007 & 7555 & 2326 & 5229 & 6457 & 2152 & 667 & 5896 & -6054 \\
\hline 2008 & 7752 & 2342 & 5410 & 4843 & 1614 & 500 & 5910 & -144 \\
\hline 2009 & 7953 & 2403 & 5550 & 3632 & 1211 & 375 & 5925 & 5782 \\
\hline 2010 & 8160 & 2465 & 5695 & 2724 & 908 & 281 & 5976 & \\
\hline 2011 & 7928 & 2530 & 5398 & 2043 & 681 & 211 & 5610 & \\
\hline 2012 & 8134 & 2458 & 5676 & 1532 & 511 & 158 & 5835 & \\
\hline 2013 & 8346 & 2522 & 5824 & 1149 & 383 & 119 & 5943 & \\
\hline 2014 & 8159 & 2587 & 5572 & 862 & 287 & 89 & 5661 & \\
\hline 2015 & 8194 & 2529 & 5665 & 646 & 215 & 67 & 5732 & \\
\hline 2016 & 8406 & 2540 & 5866 & 485 & 162 & 50 & 5916 & \\
\hline 2017 & 8625 & 2606 & 6019 & 364 & 121 & 38 & 6057 & \\
\hline 2018 & 6721 & 2674 & 4047 & 273 & 91 & 28 & 4075 & \\
\hline 2019 & 6896 & 2084 & 4812 & 205 & 68 & 21 & 4834 & \\
\hline 2020 & 6730 & 2138 & 4592 & 153 & 51 & 16 & 4608 & \\
\hline 2021 & 4670 & 2086 & 2584 & 115 & 38 & 12 & 2596 & \\
\hline 2022 & 4791 & 1448 & 3343 & 86 & 29 & 9 & 3352 & \\
\hline 2023 & 4916 & 1485 & 3431 & 65 & 22 & 7 & 3437 & \\
\hline 2024 & 5044 & 1524 & 3520 & 49 & 16 & 5 & 3525 & \\
\hline 2025 & 25233 & 1564 & 23669 & 36 & 12 & 4 & 23673 & \\
\hline & & 7822 & -7822 & & & & -7822 & \\
\hline & & & & & & & & \\
\hline IRR: & & & & & & & $9.49 \%$ & \\
\hline & & & & & & & & \\
\hline NPV(6.9\%) & & & & & & & 13982 & \\
\hline NPV(8.44\% & & & & & & & 5069 & \\
\hline
\end{tabular}


Figure 4. Total Project Costs During the Period 1997-2000

\begin{tabular}{|c|c|c|c|c|c|c|c|c|}
\hline \multirow{3}{*}{$\begin{array}{c}\text { Col. } 1 \\
\text { Month } \\
\end{array}$} & \multirow{3}{*}{\begin{tabular}{|c|} 
Col. 2 \\
Payments to \\
contractor \\
\end{tabular}} & \multirow{3}{*}{\begin{tabular}{|c|} 
Col. 3 \\
Front end fee $\&$ \\
guarantee fees \\
\end{tabular}} & Col. 4 & Col. 5 & Col. 6 & Col. 7 & \multirow{3}{*}{\begin{tabular}{|c|} 
Col. 8 \\
Discount factors \\
(at $7.00 \%$ pa) \\
\end{tabular}} & \multirow{3}{*}{$\begin{array}{r}\text { Col. } 9 \\
\text { NPV } \\
\end{array}$} \\
\hline & & & \multicolumn{2}{|c|}{ Commitment Interest on loan } & \multicolumn{2}{|c|}{ Outstanding } & & \\
\hline & & & fees & (at $6.47 \%$ pa) & loan & Investment & & \\
\hline & $£^{\prime} 000$ & $£^{\prime} 000$ & $£^{\prime} 000$ & $£^{\prime} 000$ & $£^{\prime} 000$ & $£^{\prime} 000$ & & $£^{\prime} 000$ \\
\hline Oct-97 & 2000 & 300 & & & 2300 & & & \\
\hline Dec-97 & & & 279 & 36 & 2615 & & & \\
\hline Mar-98 & & & 277 & 41 & 2933 & & & \\
\hline Jun-98 & & & 275 & 46 & 3255 & & & \\
\hline Sep-98 & & & 274 & 51 & 3580 & & & \\
\hline Dec-98 & & 222.8 & 272 & 57 & 4131 & & & \\
\hline Mar-99 & 10872 & & 269 & 65 & 15338 & & & \\
\hline Apr-99 & 5292 & & & 80 & 20710 & & & \\
\hline May-99 & 7812 & & & 109 & 28631 & & & \\
\hline Jun-99 & 5712 & & 147 & 150 & 34640 & & & \\
\hline Jul-99 & 5376 & & & 182 & 40197 & & & \\
\hline Aug-99 & 4200 & & & 211 & 44608 & & & \\
\hline Sep-99 & 504 & & 67 & 234 & 45413 & & & \\
\hline Oct-99 & 2197 & & & 238 & 47848 & & & \\
\hline Nov-99 & 2510 & & & 251 & 50608 & & & \\
\hline Dec-99 & 2510 & 222.8 & 37 & 265 & 53643 & 53643 & 1 & 53643 \\
\hline Jan-00 & 4707 & & & & & 4707 & 0.9944 & 4681 \\
\hline Feb-00 & 5021 & & & & & 5021 & 0.9888 & 4965 \\
\hline Mar-00 & 5787 & & & & & 5787 & 0.9832 & 5690 \\
\hline Dec-00 & & 222.8 & & & & 222.8 & 0.9346 & 208.2 \\
\hline Dec-01 & & 222.8 & & & & 222.8 & 0.8734 & 194.6 \\
\hline Dec-02 & & 222.8 & & & & 222.8 & 0.8163 & 181.9 \\
\hline & & & & & & & & \\
\hline Total inv & jestment at De & cember 31, 1999: & & & & & & 69563 \\
\hline Incremer & ntal costs assoc & ciated with the loa & & & & & & 5063 \\
\hline
\end{tabular}


Figure 5. Splitting the Cash Flows Between UKH and the Bank

\begin{tabular}{|c|c|c|c|c|c|c|c|}
\hline Col. 1 & Col. 2 & Col. 3 & Col. 4 & Col. 5 & Col. 6 & Col. 7 & Col. 8 \\
\hline Year & After tax & \multicolumn{4}{|c|}{ Bank Cash Flow } & \multicolumn{2}{|c|}{ Leaseco Cash Flow } \\
\hline & cash flow & Capital & Outstanding & Interest & Total & Tax credit on & Total \\
\hline & & payments & Loan & Payments & & interest paid & \\
\hline & $£^{\prime} 000$ & $£^{\prime} 000$ & $£^{\prime} 000$ & $£^{\prime} 000$ & $£^{\prime} 000$ & & $£^{\prime} 000$ \\
\hline 1999 & -69500 & -58000 & -58000 & & -58000 & & -11500 \\
\hline 2000 & 11432 & 5000 & -53000 & 5435 & 10435 & 1685 & 997 \\
\hline 2001 & 8188 & 5000 & -48000 & 4966 & 9966 & 1539 & -93 \\
\hline 2002 & 7251 & 5000 & -43000 & 4498 & 9498 & 1394 & -707 \\
\hline 2003 & 6548 & 5000 & -38000 & 4029 & 9029 & 1249 & -1087 \\
\hline 2004 & 6715 & 4000 & -34000 & 3561 & 7561 & 1104 & 403 \\
\hline 2005 & 6291 & 4000 & -30000 & 3186 & 7186 & 988 & 209 \\
\hline 2006 & 6126 & 4000 & -26000 & 2811 & 6811 & 871 & 303 \\
\hline 2007 & 5896 & 4000 & -22000 & 2436 & 6436 & 755 & 331 \\
\hline 2008 & 5910 & 4000 & -18000 & 2061 & 6061 & 639 & 604 \\
\hline 2009 & 5925 & 4000 & -14000 & 1687 & 5687 & 523 & 877 \\
\hline 2010 & 5976 & 4000 & -10000 & 1312 & 5312 & 407 & 1187 \\
\hline 2011 & 5610 & 2000 & -8000 & 937 & 2937 & 290 & 3080 \\
\hline 2012 & 5835 & 2000 & -6000 & 750 & 2750 & 232 & 3376 \\
\hline 2013 & 5943 & 2000 & -4000 & 562 & 2562 & 174 & 3613 \\
\hline 2014 & 5661 & 2000 & -2000 & 375 & 2375 & 116 & 3460 \\
\hline 2015 & 5732 & 2000 & 0 & 187 & 2187 & 58 & 3661 \\
\hline 2016 & 5916 & & & & 0 & 0 & 5974 \\
\hline 2017 & 6057 & & & & 0 & 0 & 6057 \\
\hline 2018 & 4075 & & & & 0 & 0 & 4075 \\
\hline 2019 & 4834 & & & & 0 & 0 & 4834 \\
\hline 2020 & 4608 & & & & 0 & 0 & 4608 \\
\hline 2021 & 2596 & & & & 0 & 0 & 2596 \\
\hline 2022 & 3352 & & & & 0 & 0 & 3352 \\
\hline 2023 & 3437 & & & & 0 & 0 & 3437 \\
\hline 2024 & 3525 & & & & 0 & 0 & 3525 \\
\hline 2025 & 23673 & & & & 0 & 0 & 23673 \\
\hline 2026 & -7822 & & & & 0 & & -7822 \\
\hline \multicolumn{2}{|c|}{ Internal Rate of Return } & & & & $937 \%$ & f8 35527 & $1070 \%$ \\
\hline \multicolumn{4}{|c|}{ Net Present Value at discount rate of $13.8 \%$} & & $-£ 10,085$ & & $-£ 4,254$ \\
\hline
\end{tabular}

